\title{
PARATE EKSEKUSI: HAK KREDITUR, YANG MENDEROGASI HUKUM FORMIL (SUATU PEMAHAMAN DASAR DAN MENDALAM)
}

\author{
Teddy Anggoro ${ }^{1}$
}

\section{Abstrak}

This paper explains concerning one of the ways execution of security goods, by the name parate eksekusi. In which practice, happened not full understood about this execution concept. This fact, can visible from difficulty of creditor will do the execution, because must passed formalities of prosedural law. Actualy, parate execution is exlusion of procedural law formality which is court institution do not have competency here. In this matter appropriate with means and purpose that parate eksekusi.

Kata kunci: hukum jaminan kebendaan, parate eksekusi, hukum acara perdata

\section{Pendahuluan}

Aspek jaminan dalam suatu perikatan hutang-piutang adalah faktor yang sangat penting untuk terealisinya perbuatan hukum tersebut. Seorang kreditur barulah akan memberikan pinjaman kepada debitur apabila kreditur tersebut mendapatkan kepastian bahwa piutangnya tersebut akan dilunasi dikemudian hari. Dalam hukum perdata Indonesia lembaga jaminan ini dibagi menjadi dua pengaturan, yaitu (1) Jaminan Umum, sebagaimana diatur dalam Pasal 1131 dan 1132 KUHPerdata bahwa terhadap segala harta kekayaan kreditur yang sudah maupun baru akan ada dikemudian hari menjadi jaminan bagi perikatan yang dibuat oleh debitur, dimana terhadap harta kekayaan tersebut akan dibagi pond's pond's kepada seluruh kreditur (dalam hal kreditur lebih dari satu); (2) Jaminan Khusus, sebagaimana diatur dalam Pasal 1132-1133 KUHPerdata bahwa diantara kreditur terdapat hak didahulukan bagi pelunasan hak tagihnya dan kemudahan terhadap pelunasan hak tagihnya karena tidak perlu menunggu pembagian secara pond's pond's

1 Sarjana Hukum Fakultas Hukum Universitas Indonesia Tahun 2007. Saat mahasiswa aktif dalam diberbagai organisasi kemahasiswaan, seperti Himpunan Mahasiswa Islam Komisariat FHUI, Lembaga Kajian Keilmuan FHUI, Pers Film dan Fotografi Mahasiswa FHUI dan Law Student Association for Legal Practice FHUI. 
seperti kreditur konkuren yang diatur dalam Pasal 1132 KUHPerdata, karena kreditur tersebut memegang hak istimewa atau hak-hak kebendaan yang memberikan jaminan, seperti gadai, hipotik, hak tanggungan dan fidusia, yang oleh Wirjono Prodjodikoro disebut sebagai hak-hak jaminan yang bersifat perbendaan (zakelijk zekerheidsrechten). ${ }^{2}$ Hak-hak jaminan yang bersifat perbendaan ini, berisi hak untuk pelunasan hutang saja (verhaalsrecht) dan tidak mengandung hak untuk memiliki bendanya, namun diberikan hak oleh undang-undang maupun hak untuk memperjanjikan kuasa untuk menjual sendiri obyek jaminan tersebut, ketika dikemudian hari debitur wanprestasi. ${ }^{3}$

Dalam hak-hak jaminan yang bersifat perbendaan (terkait dengan sifatnya yang didahulukan dan memudahkan bagi pelunasan hak tagihnya), terdapat lembaga-lembaga yang merupakan keistimewaan dari lembaga jaminan khusus. Salah satunya adalah lembaga Parate Eksekusi (yang dibahas dalam penulisan ini), yaitu hak seorang kreditur untuk melakukan penjualan atas kekuasaannya sendiri atau seolah-olah miliknya sendiri, benda-benda yang telah dijaminkan oleh debitur bagi pelunasan hutangnya, dimuka umum dengan syarat-syarat yang lazim berlaku, dengan sangat sederhana karena tanpa melibatkan debitur dan tanpa (fiat) izin hakim dan titel eksekutorial.

Bila kita melihat pengertian diatas maka tampak sekali bahwa parate eksekusi ini, memberikan posisi yang sangat terlindungi bagi kreditur. Patutlah dipahami mengapa pembuat undang-undang memberikan hak tersebut bagi kreditur, yaitu semata-mata agar kreditur mendapat kedudukan yang lebih baik bagi pelunasan hak tagihnya dan sangat terkait dengan hak jaminan khusus yang dipegangnya, karena seolah-olah debitur telah menyisihkan sebagian atau seluruh harta kekayaannya untuk pelunasan hutangnya apabila dikemudian hari ia wanprestasi. Mengenai alasan pembuat undang-undang memberikan hak parate eksekusi pada kreditur akan dijelaskan lebih lanjut nanti.

2 Wirjono Prodjodikoro, "Hukum Perdata Tentang Hak Atas Benda", cet. ke-5, (Jakarta: Intermasa, 1986), hal. 75.

${ }^{3}$ Sri Soedewi Masjchoen Sofwan, "Hukum Perdata: Hukum Benda", cet. ke-4, (Yogyakarta: Liberty, 1981), hal. 103. 


\section{Pengaturan Parate Eksekusi Atas Gadai, Hipotik, Hak Tanggungan Dan Fidusia}

\section{A. Gadai}

Pengaturan parate eksekusi dalam gadai diatur dalam Pasal 1155 Ayat (1) KUHPerdata, yang menyatakan:

"Bila oleh pihak-pihak yang berjanji tidak disepakati lain, maka jika debitur atau pemberi gadai tidak memenuhi kewajibannya, setelah lampaunya jangka waktu yang ditentukan, atau setelah dilakukan peringatan untuk pemenuhan janji dalam hal tidak ada ketentuan tentang jangka waktu yang pasti, kreditur berhak untuk menjual barang gadainya dihadapan umum menurut kebiasaankebiasaan setempat dan dengan persyaratan yang lazim berlaku, dengan tujuan agar jumlah utang itu dengan bunga dan biaya dapat dilunasi dengan hasil penjualan itu;

Berdasarkan ketentuan pasal tersebut diatas patutlah dipahami bahwa hak parate eksekusi ini menjadi "matang" ketika syarat-syarat sebagaimana diatur dalam pasal tersebut terpenuhi. Adapun syaratsyarat tersebut adalah sebagai berikut:

1. Hak parate eksekusi baru timbul, ketika para pihak tidak memperjanjikan lain mengenai cara untuk melakukan penjualan barang gadai tersebut, hal ini terkait dengan sifatnya yang menambahkan (aanvullendrecht). Dengan kata lain parate eksekusi ini merupakan hak yang diberikan oleh undang-undang atau demi hukum (by law) dan tidak perlu diperjanjikan terlebih dahulu, tetapi akan terderogasi juga oleh kesepakatan para pihak (pacta sunt servanda).

2. Parate executie otomatis timbul saat pemberi gadai wanprestasi. Dengan kata lain hak untuk mengeksekusi otomatis menjadi sempurna saat debitur melakukan wanprestasi. Mengenai wanprestasi yang disyaratkan dalam pasal 1155 KUHPerdata ini, dirumuskan sebagai berikut: ${ }^{4}$

${ }^{4}$ J. Satrio, Eksekusi Benda Jaminan Gadai, Prosiding Seminar Sehari Perbankan, Aspek Hukum Corporate Financing Oleh Perbankan di Indonesia: Aturan Penegakan dan Penyelesaian Sengketa Hukum Dalam Hubungan Kreditor dan Debitor, (Jurnal Hukum dan Pembangunan FHUI, Jakarta, 2006), hal. 5. 
a. Setelah tenggang waktu yang ditentukan lampau. Hal ini merujuk pada anak kalimat "... setelah lampaunya jangka waktu yang ditentukan ...". yang tertuju pada perjanjian dengan batas akhir (verval termijn).

b. Setelah dilakukan peringatan (somasi) untuk membayar, dalam hal perjanjian yang tidak ditentukan mengenai tenggang waktu. Hal ini merujuk pada anak kalimat:

"... atau setelah dilakukan peringatan untuk pemenuhan janji dalam hal tidak ada ketentuan tentang jangka waktu yang pasti ...".

Pengaturan wanprestasi ini dihubungkan dengan kata "atau" sehingga patut dipahami bahwa ketentuan ini bersifat alternatif. Bila dalam perjanjian telah ditentukan batas waktu, maka secara otomatis hak ini "matang" ketika jangka waktu yang ditentukan tersebut lampau, sedangkan apabila tidak ditentukan mengenai waktu barulah syarat kedua dapat berjalan, yaitu wajib bagi kreditur untuk memberikan peringatan (someer) pelunasan kepada debitur, karena dengan peringatan tersebut hak parate eksekusi menjadi "matang". Dalam praktek dewasa ini verval termijn menjadi klausul yang wajib dalam setiap perjanjian, bila merujuk pada ketentuan pasal ini adalah terjadi kesalahpahaman (misunderstanding) terhadap hukum pada praktek, karena terkesan suatu parate eksekusi menjadi "afdol" ketika pihak kreditur telah memperingatkan (somasi) debitur agar memenuhi janjinya. Padahal telah dijelaskan bahwa bahwa perumusan wanprestasi tersebut bersifat alternatif, tapi dalam praktek terlihat bersifat kumulatif, bila kita melihat dari sisi kehati-hatian (dalam dunia Perbankan disebut prinsip Prudential Banking) atau menurut Wahyono Darmabrata bertujuan untuk, "menjaga kemungkinan untuk lebih memperkuat landasan kreditur untuk melakukan eksekusi". 6 maka hal tersebut dapat dipahami, tapi dari sisi kepastian hukum dan waktu maka hal itu menjadi tidak logis dan bertentangan dengan

${ }^{5} \mathrm{Hal}$ ini sangat terkait dengan ketentuan Pasal 1238 KUHPerdata, yang menyatakan:

"Debitur dinyatakan lalai dengan surat perintah, atau dengan akta sejenis itu, atau berdasarkan kekuatan dari perikatan sendiri, yaitu bila perikatan ini mengakibatkan debitur harus dianggap lalai dengan lewatnya waktu yang ditentukan."

${ }^{6}$ Wahyono Darmabrata dan Ari Wahyudi Hertanto, "Jual Beli dan Aspek Peralihan Hak Milik Suatu Benda (Dalam Konstruksi Gadai Saham)," Jurnal Hukum dan Pembangunan No. 1 Tahun ke-35 (Januari-Maret 2005): hal. 64. 
hukum yaitu ketentuan Pasal 1238 KUHPerdata. Karena persyaratan "debitur harus sudah wanprestasi" ini, sebenarnya merupakan perlindungan undang-undang kepada debitur atau pun pihak ketiga pemberi gadai dari kesewenang-wenangan kreditur untuk memindahtangankan obyek jaminan gadai setiap waktu kepada pihak ketiga. Apabila syarat wanprestasi ini dilanggar maka kreditur pemegang gadai dapat digugat untuk memberikan ganti-rugi oleh debitur dan pihak ketiga pemberi gadai, dengan dasar kreditur pemberi gadai wanprestasi (Pasal 1155 jo. Pasal 1139 KUHPerdata) atau atas dasar tindakan melawan hukum (PMH) (Pasal 1365 KUHPerdata). ${ }^{7}$ Sehingga patutlah dipahami adalah sangat tidak logis, apabila dalam praktek, seorang kreditur harus berkorban waktu terlalu banyak, karena harus berkali-kali memberikan somasi kepada debitur (dalam hal perjanjian dengan verval temijn). Sedangkan persyaratan tersebut merupakan perlindungan undang-undang kepada debitur, dengan kata lain pada praktek saat ini menggiring pada kondisi dimana seorang debitur mendapatkan "double" perlindungan, yaitu oleh undangundang dan kreditur.

1. Untuk penjualan tersebut tidak disyaratkan adanya titel eksekutorial. Pemegang gadai dapat melakukan penjualan tanpa perantara pengadilan, tanpa perlu minta bantuan juru sita, tanpa perlu mendahuluinya dengan suatu sitaan. Pemegang gadai disini menjual atas kekuasaan sendiri. ${ }^{8}$

2. Penjualan harus dilakukan dihadapan umum menurut kebiasaankebiasaan setempat dan syarat-syarat yang lazim berlaku (lelang). Adapun tujuan penjualan dimuka umum ini, anak kalimat terakhir Pasal 1155 Ayat (1) KUHPerdata menjelaskan “... dengan tujuan agar jumlah utang itu dengan bunga dan biaya dapat dilunasi dengan hasil penjualan itu". Terlepas dari tujuan yang diatur dalam pasal tersebut, bila dikaitkan dengan ketentuan Pasal 1155 Ayat $(2)^{9}$ bahwa persyaratan penjualan dimuka umum tersebut

${ }^{7}$ Satrio, Eksekusi Benda Jaminan Gadai, Op. Cit., hal. 5.

${ }^{8}$ Menurut J. Satrio dalam salah-satu sesi dalam Seminar Sehari Perbankan yang diadakan oleh Jurnal Hukum Dan Pembangunan FHUI pada tanggal 17 Juli 2006. Bahwa dalam prakteknya tidaklah demikian, karena untuk penjualan melalui kantor lelang negara, dengan dikeluarkannya Putusan Yurisprudensi Mahkamah Agung No. $3210 \mathrm{~K} / \mathrm{Pdt} / 1984$ maka kantor lelang baru mau akan melelang jika ada persetujuan (fiat eksekusi) dari Pengadilan.

${ }^{9}$ Pasal 1155 Ayat (2), menyatakan: 
terdapat pengecualiannya, asalkan syarat-syarat dalam Pasal 1155 Ayat (2) tersebut terpenuhi. Sehingga patutlah dipahami bahwa inti dari penjualan barang gadai adalah untuk mendapatkan harga pasar. Mengenai tujuan penjualan umum ini akan dibahas lebih lanjut pada pembahasan berikutnya.

\section{B. Hipotik}

Pengaturan parate eksekusi dalam hipotik diatur dalam Pasal 1178 Ayat (2) KUHPerdata, yang menyatakan:

"Namun diperkenankanlah kepada pemegang hipotik pertama untuk, pada waktu diberikannya hipotik, dengan tegas minta diperjanjikan bahwa, jika utang pokok tidak dilunasi semestinya, atau jika bunga hutang tidak dibayar, ia secara mutlak akan dikuasakan menjual persil yang diperikatkan, dimuka umum, untuk mengambil pelunasan utang pokok, maupun bunga serta biaya, dari pendapatan penjualan itu. Janji tersebut harus dibukukan dalam register-register umum, sedangkan penjualan lelang harus dilakukan menurut cara sebagaimana diatur dalam Pasal 1211".

Berbeda dengan gadai, hak parate eksekusi dalam hipotik, undang-undang mensyaratkan bahwa hal ini harus dengan tegas diperjanjikan. $^{10}$ Seperti hak parate eksekusi dalam gadai maka terhadap hipotik, hak tersebut muncul dengan syarat, sebagai berikut:

1. Klasula ini harus dengan tegas diperjanjikan

Seperti telah disebutkan sebelumnya bahwa hak ini timbul apabila dengan tegas diperjanjikan oleh para pihak. Tapi pada prakteknya semua Akta Hipotik yang sudah tercetak selalu mengandung klausula janji kekuasaan untuk menjual ini. ${ }^{11}$ Bahkan karena janji sebagaimana dimaksud Pasal 1178 Ayat (2) ini selalu

"Bila gadai itu terdiri dari barang dagangan atau dari efek-efek yang dapat diperdagangkan dalam bursa, maka penjualannya dapat dilakukan di tempat itu juga, asalkan dengan perantara dua orang makelar yang ahli dalam bidang itu".

10 J. Satrio, "Parate Eksekusi Sebagai Sarana Mengahadapi Kredit Macet", (Bandung: Citra Aditya Bakti, 1s 13), hal. 19.

${ }^{11}$ Ibid., hal. 19. 
diperjanjikan, maka Veegens dan Oppenheim mengatakannya sebagai: "eene vaste, men mag zeggen nimmer ontbrekende formula geworden", yang diterjemahkan sebagai "suatu formula tetap dan dapat dikatakan tidak pernah dilupakan". 12

2. Janji tersebut harus dilakukan pada saat pemberian hipotik

Didalam Pasal 1178 Ayat (2) mengatur dengan ketat (keharusan), memperjanjikan hak parate eksekusi tersebut dilakukan pada saat diberikannya hipotik. Karena hipotik diberikan pada saat akta hipotik ditandatangani, maka J. Satrio menyatakan "... janji itu harus dimuat dalam akta hipotiknya. Disusulkan dan diperjanjikan dalam akta lain tidak bisa." Namun dalam praktek dewasa ini, sebagaimana telah dijelaskan diatas bahwa dalam Akta Hipotik yang telah tercetak, klausul tersebut selalu ada.

3. Diperjanjikan oleh pemegang hipotik pertama

Bahwa undang-undang secara tegas menyebutkan pemegang hipotik pertamalah yang dapat memperjanjikan hak tersebut, tetapi patutlah dipahami bahwa undang-undang menentukan dengan tegas hal tersebut, karena didasarkan atas kekhawatiran akan munculnya kesulitan dan sengketa antara sesama kreditur pemegang hipotik. ${ }^{13}$ Tetapi bukan berarti pemegang hipotik kedua dan seterusnya tidak boleh memperjanjikan ini, karena apabila hipotik pertama hapus karena pelunasan maka otomatis pemegang hipotik dibawahnya akan bergeser keatas. ${ }^{14}$ Sehingga sangatlah logis untuk dipahami maksud pembuat undang-undang mengatur hal ini, yaitu bukan ditujukan, bahwa hanya (satu-satunya) pemegang hipotik pertama yang dapat memperjanjikan hal ini, tetapi dimaksudkan bahwa pemegang hipotik pertamalah "yang mempunyai keutamaan" untuk memperjanjikannya. Apabila pemegang hipotik pertama sudah memperjanjikan maka barulah pemegang hipotik berikutnya dapat memperjanjikan ini, karena apabila dalam prakteknya, terjadi pemegang hipotik pertama tidak memperjanjikan hal ini, sedangkan pemegang hipotik kedua memperjanjikannya maka sangatlah mungkin pemegang hipotik

${ }^{12}$ Ibid., hal. 22. sebagaimana dikutip dari J.D. Veegens dan A.S. Oppenheim, Schets van het Nederlandsch Burgerlijk Recht, (Tjeenk Willink Haarlem, 1919), hal. 245-246.

${ }^{13}$ Ibid., hal. 21.

${ }^{14}$ Ibid. sebagaimana dikutip dari P. Scholten, Serie Asser, Handleiding tot de beoefening van het Nederlands Burgerlijk Recht, Jilid Kedua Zakenrecht, Cet. 6, (Tjeeng Willing Zwolle, 1927), hal. 487. 
kedua menjual (menggunakan hak ini) obyek yang telah dijaminkan hipotik sedangkan pemegang pertama tidak dapat melakukannya karena tidak memperjanjikannya. Sehingga dalam kondisi ini sangat mungkin terjadi pelanggaran ketentuan Pasal 1136 KUHPerdata. ${ }^{15}$

4. Adanya kewenangan bersyarat dimana debitur harus sudah wanprestasi

Kewenangan kreditur untuk melaksanakan hak jualnya digantungkan pada syarat, "... jika utang pokok tidak dilunasi semestinya atau jika bunga yang terhutang tidak dibayar". Dengan demikian maka dapat disimpulkan bahwa "kewenangan menjual tersebut baru jalan/hidup, kalau debitur sudah wanprestasi". ${ }^{16}$ Sebagai tambahan pemahaman mengenai hal ini, patutlah diketahui ketentuan Pasal 1238 KUHPerdata $^{17}$ yang mengatur dalam keadaan apa seorang kreditur dikatakan berada dalam keadaan lalai. Tetapi sekali lagi saya tegaskan (seperti pembahasan mengenai hak parate eksekusi gadai) bahwa dalam hal perjanjian pokoknya sudah mengatur mengenai tenggang waktu pembayaran hutang, maka dengan lewatnya waktu yang diperjanjikan tersebut, sudah merupakan bukti nyata akan kelalaian debitur (default clause), ${ }^{18}$ sehingga tidak perlukan lagi adanya somasi. Tetapi sekali lagi ditegaskan bahwa dalam prakteknya hal ini disimpangi.

5. Kuasanya Mutlak

Pasal ini menentukan, adalah kewenangan kreditur untuk memperjanjikan "secara mutlak" kuasa untuk menjual ini. Mutlak disini dipadankan dengan kata "onherroepelijk" (tidak dapat ditarik kembali), hal ini merupakan lex specialis dari

${ }^{15}$ Pasal 1136 KUHPerdata, menyatakan: "Para kreditur dengan hak didahulukan yang mempunyai tingkatan sama, dibayar secara berimbang".

${ }^{16}$ Satrio, Parate Eksekusi, Op. Cit., hal. 22.

${ }^{17}$ Pasal 1238 KUHPerdata, menyatakan:

"Debitur dinyatakan lalai dengan surat perintah, atau dengan akta sejenis itu, atau berdasarkan kekuatan dari perikatan ini mengakibatkan debitur haru dianggap lalai dengan lewatnya waktu yang ditentukan".

18 Setiawan, "Aneka Masalah Hukum Dan Hukum Acara Perdata", (Bandung: Alumni, 1992), hal. 229. 
ketentuan Pasal 1813 KUHPerdata ${ }^{19}$ yang mengatur mengenai hal-hal yang mengakhiri "lastgeving" (perjanjian pemberian kuasa). Pada prakteknya, J. Satrio menjelaskan, bahwa dalam akta hipotik dicantumkan kalimat, "juga tidak akan berakhir karena sebab-sebab sebagaimana disebutkan dalam Pasal 1813 KUHPerdata". ${ }^{20}$

6. Harus didaftarkan

Maksud didaftarkan disini tertuju pada akta hipotik yang didalamnya termuat janji tersebut. Jadi bukan janji menjualnya yang didaftarkan tetapi akta yang memuat janjinya. Tetapi sekali lagi dalam akta hipotik yang tercetak, janji menjual ini sudah termasuk didalamnya. Sehingga saat akta tersebut didaftarkan, maka otomatis janji tersebut pun terdaftar.

7. Penjualan dimuka umum

Penjualan dimuka umum ini maksudnya adalah penjualan harus melalui lelang dan harus dilakukan dihadapan pejabat umum ${ }^{21}$ (jurù lelang). ${ }^{22}$ Adapun mengenai tempat penjualan adalah tempat dimana obyek hipotik tersebut terletak, dengan demikian dilakukan melalui Kantor Lelang yang membawahi wilayah dimana obyek hipotik tersebut terdaftar. ${ }^{23}$

8. Memperhatikan ketentuan Pasal 1211

Pada saat kita membicarakan ketentuan Pasal 1211 KUHPerdata $^{24}$ yang merupakan syarat penjualan obyek hipotik, maka tidak lah

\footnotetext{
${ }^{19}$ Pasal 1813 KUHPerdata, menyatakan:
}

"Pemberian kuasa berakhir: dengan penarikan kembali kuasa penerima kuasa; dengan pemberitahuan kuasanya oleh penerima kuasa; dengan meninggalnya, pengampuan atau pailitnya, baik pemberi kuasa maupun penerima kuasa; dengan kawinnya perempuan yang memberikan atau menerima kuasa".

${ }^{20}$ Satrio, Parate Eksekusi, Op. Cit., hal. 23.

${ }^{21}$ Sebelum diadakan pengaturan bahwa penjualan umum harus dilakukan oleh juru lelang maka yang maksud dengan pejabat umum adalah Notaris. Selain itu terdapat pula penjualan umum dibawah pengawasan pengadilan. Satrio, Ibid. hal. 25.

${ }^{22}$ Kewenangan juru lelang didasarkan pada ketentuan Pasal 1 Huruf (a) Peraturan Lelang (Vendu-Reglement) S.1908 No. 189, yang menyatakan: "Semua penjualan umum harus dilakukan dihadapan juru lelang."

${ }^{23}$ Satrio, Parate Eksekusi, Op. Cit., hal. 26. 
lepas dari ketentuan Pasal 1210 KUHPerdata, ${ }^{25}$ dimana dalam pasal ini mengatur mengenai pemurnian obyek hipotik terhadap beban-beban hipotik yang dimiliki oleh pemegang hipotik lainnya. Tetapi maksud dari mengindahkan ketentuan Pasal 1112 KUHPerdata ini adalah merujuk pada cara parate eksekusi yang diatur dalam pasal ini. Jadi bukan pada permasalahan pembersihan obyek hipotik (yang telah dibeli oleh pihak ketiga) dari beban hipotik, pemegang hipotik lainnya.

Tetapi terkait dengan pengaturan parate eksekusi terhadap obyek hipotik, saat ini hanya berlaku bagi obyek hipotik yang berupa kapal dengan volume kotor paling sedikit $20 \mathrm{~m}^{3}$, hal ini sebagaimana diatur dalam Pasal 314 KUHDagang. ${ }^{26}$ Mengenai tanah dan segala sesuatu

\footnotetext{
${ }^{24}$ Pasal 1211 KUHPerdata, menyatakan:
}

"Dalam hal penjualan sukarela, tuntutan untuk pembebasan tidak dapat diajukan, kecuali bila penjualan itu telah terjadi di depan umum menurut kebiasaan setempat, dan dihadapan pegawai umum, selanjutnya, para kreditur yang terdaftar perlu diberitahukan tentang hal itu, selambatlambatnya tiga puluh hari sebelum barang yang bersangkutan ditunjuk pembeli, dengan surat juru sita yang harus disampaikan di tempat-tempat tinggal yang telah dipilih oleh para kreditur itu pada waktu pendaftaran".

${ }^{25}$ Pasal 1210 KUHPerdata, menyatakan:

“Orang yang telah membeli barang yang berbeban, baik pada penjualan sebagai pelaksanaan putusan Hakim atas tuntutan mengenai pemilikan atau penguasaan, maupun pada penjualan sukarela untuk harga yang ditentukan dalam bentuk uang, dapat menuntut agar persil yang dibelinya dibebaskan dari segala beban hipotek yang melampaui harga pembeliannya, dengan menaati segala peraturan yang diberikan dalam pasal-pasal berikut. Namun pemurnian itu tidak akan terjadi pada penjualan sukarela, bila pihak-pihak yang berjanji pada waktu mengadakan hipotek telah menyepakati hal itu dan persyaratan perjanjian itu telah didaftarkan dalam daftar umum. Persyaratan perjanjian demikian hanya dapat dibuat oleh kreditur hipotek pertama"

${ }^{26}$ Pasal 314 KUHDagang, menyatakan:

“Kapal-kapal Indonesia, yang berukuran paling sedikit $20 \mathrm{~m}^{3}$ (duapuluh meter kubik) isi kotor, dapat dibukukan didalam suatu register kapal menurut ketentuan-ketentuan yang akan ditetapkan dalam suatu undangundang;

Dalam undang2 ini harus pula diatur tentang caranya peralihan hak milik dan penyerahan akan kapal-kapal atau kapal2 dalam pembuatan yang 
yang berkaitan dengan tanah, yang selama ini merupakan obyek hipotik, dikeluarkan dan dimasukkan ke dalam objek hak tanggungan, hal ini sesuai dengan pengaturan Pasal $29^{27}$ Jo. Pasal $1^{28}$ UndangUndang No. 4 Tahun 1996 Tentang Hak Tanggungan. Bila kita meninjau kapal dari sifatnya maka sangat nyata terlihat bahwa kapal adalah benda bergerak, ${ }^{29}$ tetapi karena undang-undang, kapal dengan volume $20 \mathrm{~m}^{3}$ menjadi ditentukan menjadi benda tetap. Hal ini terkait dengan juga dengan kewajiban pendaftaran kapal dan pendaftaran balik nama dalam penyerahan kapal, yang merupakan ciri penting dari benda tetap. Dalam anak kalimat terakhir Pasal 314 Ayat (3)

dibukukan dalam register kapal tersebut, dan andil-andil dalam kapalkapal atau kapal-kapal dalam pembuatan şeperti itu dapat diletakkan hipotik.

Atas kapal2 yang disebutkan dalam ayat kesatu, tidak dapat diletakkan hak gadai. Atas kapal2 yang dibukukan tak berlakulah pasal 1977 Kitab Undang2 Hukum Perdata".

27 Pasal 29 Undang-Undang No. 4 Tahun 1996 Tentang Hak Tanggungan, menyatakan:

"Dengan berlakunya Undang-Undang ini, ketentuan mengenai Credietverband sebagaimana tersebut dalam Staatsblad 1908-542 jo.Staatsblad 1909-586 dan Staatsblad 1909-584 sebagai yang telah diubah dengan Staatsblad 1937-190 jo. Staatsblad 1937-191 dan ketentuan mengenai Hypotheek sebagaimana tersebut dalam Buku II Kitab Undang-Undang Hukum Perdata Indonesia sepanjang mengenai pembebanan Hak Tanggungan pada hak atas tanah beserta benda-benda yang berkaitan dengan tanah dinyatakan tidak berlaku lagi".

28 Pasal 1 Undang-Undang No. 4 Tahun 1996 Tentang Hak Tanggungan, menyatakan:

"Hak Tanggungan atas tanah beserta benda-benda yang berkaitan dengan tanah, yang selanjutnya disebut Hak Tanggungan, adalah hak jaminan yangdibebankan pada hak atas tanah sebagaimana dimaksud dalam Undang-Undang Nomor 5Tahun 1960 tentang Peraturan Dasar Pokok-Pokok Agraria, berikut atau tidakberikut benda-benda lain yang merupakan satu kesatuan dengan tanah itu, untukpelunasan utang tertentu, yang memberikan kedudukan yang diutamakan kepada kreditor tertentu terhadap kreditor-kreditor lain".

29 J. Satrio, "Hukum Jaminan Hak Jaminan Kebendaan", (Bandung: Citra Aditya Bakti, 2002), hal. 192. 
KUHPerdata, ditegaskan “...Atas kapal2 yang dibukukan tak berlakulah pasal $1977^{30}$ Kitab Undang2 Hukum Perdata”.

Selain itu patutlah dipahami bahwa terhadap kapal-kapal sebagaimana diatur dalam Pasal 314 KUHDagang tersebut, tidaklah mutlak, hipotik menjadi satu-satunya lembaga jaminan yang dapat diletakkan terhadap kapal-kapal tersebut. Hal ini mengacu pada kata "dapat" dalam kalimat "... seperti itu dapat diletakkan hipotik". Jadi selain hipotik, terhadap kapal-kapal tersebut dapat dibebani jaminan khusus lainnya, dengan perkataan lain ayat dalam pasal ini hanya ingin mengatakan "apabila dikehendaki, maka atas kapal-kapal seperti itu bisa diletakkan jaminan hipotik". ${ }^{31}$

\section{Hak Tanggungan}

Pengaturan mengenai parate eksekusi hak tanggungan, diatur dalam Pasal 6 Undang-Undang Hak Tanggungan, yaitu;

"Apabila debitur cidera janji, pemegang Hak Tanggungan pertama mempunyai hak untuk menjual obyek Hak Tanggungan atas kekuasaan sendiri melalui pelelangan umum serta mengambil pelunasan piutangnya dari hasil penjualan tersebut".

Apabila kita melihat ketentuan pasal 6 ini maka terlintas dipikiran bahwa Undang-Undang Hak Tanggungan mengatur parate eksekusi layaknya pengaturan parate eksekusi dalam gadai, yaitu hak tersebut diberikan oleh Undang-Undang/demi hukum (by law) tanpa diperjanjikan terlebih dahulu (bedakan dengan ketentuan parate eksekusi hipotik yang mensyaratkan bahwa hal ini harus dengan tegas

${ }^{30}$ Pasal 1977 KUHPerdata, menyatakan:

"Barangsiapa menguasai barang bergerak yang tidak berupa bunga atau piutang yang tidak harus di bayar atas tunjuk, dianggap sebagai pemiliknya sepenuhnya;

Walaupun demikian, barangsiapa kehilangan atau kecurian suatu barang, dalam jangka waktu tiga tahun, terhitung sejak hari barang itu hilang atau dicuri itu dikembalikan pemegangnya, tanpa mengurangi hak orang yang disebut terakhir ini untuk minta ganti rugi kepada orang yang menyerahkan barang itu kepadanya, pula tanpa mengurangi ketentuan Pasal 582".

${ }^{31}$ Satrio, Hukum Jaminan, Op. Cit. hal. 192. 
diperjanjikan. Pen.). ${ }^{32}$ Sekali lagi ditekankan, bahwa ini adalah yang tampak nyata-nyata dengan membaca pasal ini.

Berdasarkan pasal tersebut diatas, maka dapat disimpulkan bahwa ketentuan Hak Tanggungan mengadaptasi (bedakan dengan adopsi) ketentuan hipotik, yaitu hak kreditur yang bersyarat. Dengan syaratsyarat sebagai berikut:

1. Hak tersebut menjadi "matang" ketika debitur cidera janji

Sama seperti gadai dan hipotik, bahwa hak ini diakomodir didalam undang-undang sebagai sarana bagi kreditur untuk dimudahkan dalam mendapatkan pelunasan hak tagihnya. Sarana tersebut dibutuhkan bagi kreditur, ketika kreditur merasa "terancam" piutangnya tidak dilunasi.(lihat, penjelasan syaratsyarat hipotik)

2. Merupakan hak Pemegang Hak Tanggungan pertama

Sekali lagi ditekankan, apabilå pengaturan Hak Tanggungan mengadaptasi pengaturan hipotik, maka patutlah dipahami bahwa tujuan pembuat undang-undang mencantumkan kata "pemegang hipotik pertama" dalam pengaturan parate eksekusi hipotik adalah agar jangan sampai terjadi pemegang hak yang pertama tidak memperjanjikan parate eksekusi ini, sedangkan pemegang kedua dan seterusnya memperjanjikan (lihat, penjelasan syarat-syarat hipotik). Bila kita menikuti logika berfikir diatas diatas, bahwa Parate Eksekusi dalam pasal ini diberikan undang-undang atau demi hukum, maka apakah pemegang Hak Tanggungan Kedua dan seterusnya tidak dapat memperjanjikan hal tersebut?

3. Penjualan melalui pelelangan umum

Sebagai gambaran, pada pengaturan parate eksekusi gadai dan hipotik dengan tegas undang-undang menyatakan bahwa tujuan penjualan lelang adalah untuk mengambil pelunasan hutang pokok, bunga dan biaya. Tapi pada ketentuan Hak Tanggungan hal tersebut dibedakan dengan menghubungkan anak kalimat "melalui pelelangan umum" dan anak kalimat "mengambil pelunasan piutang" dengan kata "serta". Hal ini menunjukan bahwa pembuat undang-undang Hak Tanggungan ingin menekankan anak kalimat "melalui pelelangan umum" sebagai suatu formalitas dengan suatu conditio sine qua non (kata "serta") akan terlunasi piutang kreditur. Dengan perkataan lain, dalam masalah penjualan umum (lelang), hipotik dan gadai diri

${ }^{32}$ Satrio, Ibid. , hal. 286. 
pada rezim hukum materiil sedangkan Hak Tanggungan diposisikan oleh pembuat undang-undangnya pada rezim hukum formil.

Bila kita teruskan membaca Undang-Undang ini maka pada Pasal 11 Ayat (2) Huruf (e), diatur:

\section{"Dalam Akta Pemberian Hak Tanggungan dapat dicantumkan janji-janji ...; janji bahwa pemegang Hak Tanggungan pertama mempunyai hak untk menjual atas kekuasaan sendiri obyek Hak Tanggungan apabila debitor cidera janji".}

Dengan membaca Pasal diatas barulah dapat dipahami bahwa pengaturan parate eksekusi Hak Tanggungan sangat kental mengadopsi ketentuan parate eksekusi hipotik yang diatur dalam Pasal 1178 Ayat (2) KUHPerdata (sebagai lembaga jaminan atas tanah sebelum diberlakukannya Undang-Undang ini). Tetapi yang timbul justru kesan "mubazir" dan membingungkan, dengan dua pengaturan pasal tersebut, disatu sisi Pasal 6 mengatur bahwa hak tersebut diberikan oleh Undang-Undang (by law), sedangkan disisi lain Pasal 11 Ayat (2) Huruf (e) menyatakan bahwa hak tersebut diperjanjikan oleh para pihak sehingga terkesan pengaturan yang bersifat menambahkan (annvullendrecht).

Bila kita meninjau sistematika Undang-Undang ini dengan mengaitkan pada skema pemberian dan kewajiban pendaftaran Hak Tanggungan (kewajiban sehingga Hak Tanggungan dapat dikatakan lahir), yang pada intinya akan menghasilkan Sertifikat Hak Tanggungan yang memuat irah-irah "DEMI KEADILAN BERDASARKAN KETUHANAN YANG MAHA ESA"33 (pada lembaga hipotik disebut dengan grosse akta yang dibuat oleh notaris), dimana irah-irah tersebut berakibat bahwa sertifikat tersebut mempunyai kekuatan eksekutorial seperti putusan pengadilan yang mempunyai kekuatan hukum tetap. ${ }^{34}$ Maka mau tidak mau Pasal 6

33 Lihat, Pasal 14 Ayat (2) Undang-Undang No. 4 Tahun 1996 Tentang Hak Tanggungan

${ }^{34}$ Ibid., Pasal 14 Ayat (3)

Adapun penjelasannya:

"Sertifikat tersebut memiliki daya (kekuatan) eksekusi apabila pemberi hak tanggungan wanprestasi, layaknya sebuah putusan yang tidak 
tersebut tidak lebih diekspresikan sebagai sebuah "pasal bisu", karena ujung-ujungnya eksekusi harus melalui mekanisme eksekusi titel eksekutorial dari Sertifikat Hak Tanggungan tersebut, yaitu pada prakteknya harus sesuai dengan ketentuan hukum acara perdata yang berlaku, dengan fiat eksekusi dari pengadilan (200 HIR), dibawah pimpinan Ketua Pengadilan (Pasal 224 HIR dan Pasal 33 Ayat (3) Undang-Undang No. 14 Tahun 1970 Tentang Kekuasaan Kehakiman), yang semuanya dengan mengindahkan ketentuan hukum acara perdata dalam Pasal 197, Pasal 198 dan Pasal 200 HIR (bandingkan dengan tujuan pengaturan parate eksekusi, yang akan dijelaskan lebih lanjut). Meskipun Undang-Undang Hak Tanggungan mengatur cara eksekusi menjadi 2 (dua) macam, yaitu (a) dengan melakukan parate eksekusi bagi hak pemegang Hak Tanggungan pertama; dan (b) dengan Sertifikat yang telah mempunyai titel eksekutorial, berdasarkan ketentuan hukum acara perdata yang berlaku. $^{35}$ Akhirnya tetap saja, dengan kewajiban pendaftaran tersebut dan konsekuensi hukum dari Sertifikat Hak Tanggungan, maka ujung-ujungnya eksekusi harus sesuai dengan ketentuan hukum acara perdata juga (lewat pengadilan), padahal tujuan dari diberikannya titel eksekutorial tersebut adalah untuk menegaskan konsep sederhana dan memudahkan serta lebih berkepastian hukum (dibandingkan parate eksekusi) dalam eksekusi hak tanggungan tetapi pada kenyataannya justru semakin menenggelamkan konsep eksekusi yang sederhana dan memudahkan yang merupakan nafas jaminan kebendaan khusus. Oleh karena itu, penulis menilai bahwa dengan terdapatnya titel eksekutorial dalam Serifikat Hak Tanggungan dengan dikaitkan dengan kenyataan praktek dewasa ini justru membuat ketentuan Pasal 6 (yang mengatur parate eksekusi Hak Tanggungan) tersebut menjadi "Pasal Bisu".

Tapi sekali lagi amat membingungkan ketika Penjelasan Pasal 14 Ayat (2) dan (3) pada anak kalimat terakhir menyatakan "... melalui tata cara dan dengan menggunakan parate eksekusi sesuai dengan peraturan hukum acara perdata yang berlaku", dengan hal ini sangat nampak sekali bahwa pembuat undang-undang hanya memahami parate eksekusi sebagai penjualan umum semata, bukan pemahaman bahwa parate eksekusi adalah hak yang sangat essensial, yang membedakan lembaga jaminan khusus dengan jaminan umum, dimana

tersedia upaya hukum biasa lagi dan dapat langsung dilaksanakan (berkekuatan hukum tetap)."

${ }^{35}$ Lihat, Pasal 20 Ayat (1) Undang-Undang No. 4 Tahun 1996 Tentang Hak Tanggungan. 
pemegang hak baik karena undang-undang (gadai dan fidusia) maupun karena kesepakatan para pihak (hipotik dan hak tanggungan) dapat menjual atas kuasanya sendiri barang jaminan tanpa melibatkan pemberi jaminan dan perantara pengadilan, yang semata-mata bertujuan untuk memudahkan pemegang jaminan mendapatkan pelunasan atas hak tagihnya. Terkait dengan permasalahan penjelasan Pasal 14 Ayat (2) dan (3) yang membingungkan tersebut. Maka patut dipertanyakan, apakah hukum acara perdata mengatur parate eksekusi?? Jelaslah, tidak. Karena parate eksekusi adalah eksekusi yang menurut P.A. Stein disebut sebagai eksekusi yang disederhanakan, ${ }^{36}$ yang tidak mengikuti ketentuan eksekusi dalam hukum acara perdata terkait dengan sifat-sifat lembaga jaminan khusus. Dengan perkataan lain, perlu ditegaskan Hukum Acara Perdata tidak pernah mengatur mengenai Parate Eksekusi.

Kesimpulan mengenai pembahasan parate eksekusi Hak Tanggungan ini, adalah bahwa lembaga tersebut memang diatur dengan tegas oleh undang-undang yang bersangkutan, tapi sistematika Undang-Undang Hak Tanggungan sendiri yang akhirnya mengeliminir hak essensial dari lembaga jaminan khusus tersebut. Sehingga patutlah dipikirkan bahwa terdapat kesalahan persepsi dan ketumpang-tindihan dalam pengaturan eksekusi dalam Undang-Undang Hak Tanggungan.

\section{Fidusia}

Parate eksekusi pada lembaga jaminan fidusia diatur didalam dua pasal yaitu, pasal 15 Ayat (3) yang menyatakan: "Apabila debitor cidera janji, Penerima Fidusia mempunyai hak untuk menjual Benda yang menjadi objek Jaminan Fidusia atas kekuasaannya sendiri"; dan pasal Pasal 29 Ayat (1) Huruf (b) Undang-Undang No. 42 Tahun 1999 Tentang Fidusia, yang menyatakan:

"Apabila debitor atau Pemberi Fidusia cidera janji, eksekusi terhadap Benda yang menjadi objek Jaminan Fidusia dapat dilakukan dengan cara: ... b. penjualan benda yang menjadi objek Jaminan Fidusia atas kekuasaan Penerima Fidusia sendiri melalui pelelangan umum serta mengambil pelunasan piutangnya dari hasil penjualan".

Bila kita melihat pada pengaturan pasal-pasal diatas maka persyaratan "matang"nya kewenangan melakukan parate eksekusi,

${ }^{36}$ Satrio, Eksekusi Obyek Jaminan Gadai, Op. Cit., hal.4. 
hampir sama dengan pembahasan mengenai lembaga jaminan khusus sebelumnya. Hanya saja yang membedakannya dengan hipotik (dan kesamaannya dengan gadai) adalah, hak parate eksekusi dalam fidusia diberikan oleh undang-undang (by law) tanpa perlu diperjanjikan oleh para pihak. Bahkan dengan bijaknya pembuat undang-undang membuka mekanisme eksekusi obyek fidusia dengan lembaga parate eksekusi (salah satu cara disamping pelaksanaan titel eksekutorial dan penjualan dibawah tangan), hal ini ditegaskan lagi dalam penjelasan Pasal 15 Ayat (3) yang menyatakan;

"Salah satu ciri Jaminan Fidusia adalah kemudahan dalam pelaksanaan eksekusinya yaitu apabila pihak Pemberi Fidusia cidera janji. Oleh karena itu, dalam Undangundang ini dipandang perlu diatur secara khusus tentang eksekusi Jaminan Fidusia melalui lembaga parate eksekusi".

Sehingga dapatlah disimpulkan pengaturan lembaga parate eksekusi dalam fidusia identik pengaturan lembaga parate eksekusi gadai.

\section{Parate Eksekusi (Tujuan dan Sejarah)}

Telah disinggung sedikit diatas, lembaga parate eksekusi ditujukan agar kreditur mendapat kemudahan pelunasan hak tagihnya. Hal ini merupakan konsekuensi dari konsep lembaga jaminan khusus, yang sifatnya memberikan kemudahan dan kedudukan didahulukan bagi kreditur dalam mendapatkan pelunasan hak tagihnya. Sehingga patutlah dipahami bahwa dimasukkannya lembaga jaminan khusus oleh pembuat undang-undang ditujukan semata-mata bagi kepentingan kreditur, karena bila kita melihat pada sisi kepentingan debitur maka lembaga jaminan umum sudah cukup "mengakomodir". Dengan adanya kemudahan dan kedudukan didahulukan dalam lembaga jaminan khusus, maka sangat besarlah harapan pembuat undang-undang agar roda perekonomian berjalan dengan lancar, khususnya pada pada bidang pembiayaan usaha (corporate financing), dimana suatu usaha dapat dijalankan atau dapat berkembang pesat dengan adanya pinjaman hutang/kredit. Karena bagi pihak yang memberikan pinjaman akan tidak akan segan-segan untuk mengucurkan pinjaman/kreditnya kepada debitur, karena adanya perasaan aman bagi kreditur bahwa piutangnya akan dilunasi dikemudian hari, karena kreditur telah memegang hak kebendaan milik debitur yang memberikan jaminan secara khusus, yang dapat kreditur jual suatu saat apabila debitur wanprestasi. Oleh karena itu, dapatlah 
dikatakan ketika diantara kreditur dan debitur telah sepakat untuk menggunakan lembaga jaminan khusus, sebagai perjanjian accessoir dari perjanjian hutang-piutangnya/kredit, maka tersirat adanya kesepakatan dua belah pihak, dengan percakapan sebagai berikut: kreditur: "saya berikan pinjaman kepada anda (debitur), asalkan anda memberikan jaminan bahwa piutang saya, akan anda lunasi," debitur: "berikanlah pinjaman anda (kreditur), karena saya akan melunasi hutang saya dan silahkan anda pegang harta kekayaan (kebendaan) saya untuk anda ambil pelunasan piutang anda, apabila saya ingkari janji saya ini". Jadi intinya adalah kreditur memberikan pinjaman, karena adanya "kepercayaan lebih", akan pelunasan hak tagihnya.

Salah satu kemudahan bagi kreditur untuk mendapatkan pelunasan hak tagihnya, adalah dengan diakomodirnya lembaga parate eksekusi oleh undang-undang, disamping lembaga eksekusi riil dengan titel eksekutorial. ${ }^{37}$ Mengenai parate eksekusi ini, dapat kita lihat pendapat Hoogerrechtschof van Nederlands Indie (HGH) yang menyatakannya sebagai "hak untuk mengambil pelunasan tanpa putusan pengadilan", ${ }^{38}$ jadi seakan-akan hal eksekusi selalu siap (paraat) ditangan kreditur. Sejalan dengan pendapat tersebut P.A. Stein menyebutnya sebagai "eksekusi yang disederhanakan", bahkan karena sedemikian sederhananya A. Pitlo mengatakan: "De pandhouder verkoopt deze zaak als ware het zijn eigen zaak", yang biasa diterjemahkan menjadi "Pemegang gadai menjual benda tersebut seakanakan benda itu miliknya sendiri". Hal ini dikarenakan oleh pelaksanaan parate eksekusi yang tidak melibatkan debitur atau pemberi-gadai, ${ }^{39}$ dan tidak melibatkan Pengadilan dalam pelaksanaan penjualannya. ${ }^{40}$ Sejalan dengan pelaksanaan penjualan tanpa melibatkan Pengadilan ini dikatakan oleh Maria Elisabeth Elijana, mengenai apa yang dimaksud dengan Parate

37 Sudikno Mertokusumo berpendapat, Titel Eksekutorial adalah kekuatan untukdilaksanakan secara paksa dengan bantuan dan oleh alat-alat negara.

Sudikno Mertokusumo, Hukum Acara Perdata Indonesia (Yogyakarta: Liberty, 1996), hal. 211.

${ }^{38}$ HGH pada tanggal 30 Mei 1929, mengatakan: “... doch hem slechts het recht heeft gegeven, om zonder vonnis tot verhaal over te gaan" (... tetapi hanya memberikan kepadanya (merujuk pada kreditur preferen) untuk tanpa keputusan pengadilan mengambil pelunasan).

Satrio, Parate Eksekusi Sebagai Sarana Menghadapi Kredit Macet, Op. Cit., hal. 43.

${ }^{39}$ Satrio, Eksekusi Obyek Jaminan Gadai, Op. Cit., hal. 6

${ }^{40}$ Satrio, Parate Eksekusi Sebagai Sarana Menghadapi Kredit Macet, Op. Cit., hal.

43. 
Eksekusi, yaitu: "Eksekusi secara serta merta yang dapat dilakukan tanpa perantara/bantuan Pengadilan." 41

Maka dapatlah dipahami bahwa mengapa parate eksekusi dikatakan sebagai "hak mengeksekusi yang disederhanakan" atau menurut A. Pitlo "zonder omslag" atau "tanpa liku-liku", karena dalam pelaksanaannya dilakukan tanpa melibatkan debitur (menjual atas kekuasaannya sendiri) dan tanpa perantara/bantuan Pengadilan. Menurut J. Satrio dengan mensitir pendapat A. Pitlo mengatakan,

"... sebagai orang yang melaksanakan haknya sendiri (beding tot eigenmachtig verkoop) ..., bahwa dalam pelelangan ia sendiri (kreditur) yang menetapkan syarat-syaratnya, ia sendiri yang menerima hasil penjualannya dan kalau pembeli dalam lelang wanprestasi, ia sendiri yang menuntut pembatalannya". ${ }^{3}$

Maka tak heran ketika Paul Scholten menyimpulkannya hal tersebut sebagai pelaksanaan hak kreditur yang digambarkan dengan dua kata, yaitu "sederhana" dan "murah", dimana dalam bukunya Serie Asser, Handleiding tot de beoefening van het Nederlands Burgelijk Recht, Paul Scholten, mengatakan: "... een eenvoudige en onkostbare tenuitvoerlegging ... krachtens eigenrecht van den hypothecairen schuldeiser". ${ }^{44}$

Melihat dari penjelasan diatas, keistimewaan dari parate eksekusi ini terdapat pada dua hal, yaitu:

1. penjualan tanpa melibatkan debitur

hal ini terkait dengan adanya kuasa mutlak yang tidak dapat ditarik kembali "onherroepelijk" kepada kreditur, untuk menjual atas kekuasaannya sendiri. Yang didapat dengan diperjanjikan dengan tegas (seperti, hipotik dan Hak Tanggungan) atau karena diberikan oleh Undang-Undang (seperti, Gadai, Fidusia dan Hak Tanggungan dalam Pasal 6-nya).

41 Maria Elisabeth Elijana, Eksekusi Barang Jaminan Sebagai Salah Satu Cara Pengembalian Hutang Debitur, Prosiding Seminar Sehari Perbankan, Aspek Hukum Corporate Financing Oleh Perbankan di Indonesia: Aturan Penegakan dan Penyelesaian Sengketa Hukum Dalam Hubungan Kreditor dan Debitor, (Jurnal Hukum dan Pembangunan FHUI, Jakarta, 2006), hal. 56.

\footnotetext{
${ }^{42}$ Satrio, Parate Eksekusi, Op. Cit., hal. 43.

${ }^{43}$ Satrio, Ibid., hal. 40.

${ }^{44}$ Satrio, Ibid., hal. 43.
} 
2. Penjualan tanpa perantara/melalui Pengadilan Hal ini terkait dengan kuasa mutlak sebagaimana dijelaskan diatas, dan juga doktrin "eksekusi yang disederhanakan dan murah". Terbayang apabila prosedur penagihan dilakukan melalui/perantara pengadilan (baik dengan proses penetapan maupun gugatan) sampai dengan proses sitaan dan eksekusi, jelas akan memakan waktu yang lama, belum lagi apabila debitur melakukan verzet-verzetnya. Maka untuk memberikan kepastian pada kreditur dan menegakkan sifat-sifat atau essensialia lembaga jaminan khusus, hal ini sangat logis.

Berdasarkan penjelasan secara keseluruhan diatas, maka harus dipahami bahwa parate eksekusi berada dalam lingkup hukum perdata materiil, karena sangat berbeda maksud, proses dan implikasinya dengan eksekusi riil yang diatur dalam hukum perdata formil, yang oleh A. Pitlo sebagaimana disitir oleh P.A. Stein, mengatakan "... buiten het terrein der rechtvordering", (di luar wilayah hukum acara). ${ }^{45}$ Sejalan dengan pendapat ini, J. Satrio menegaskan:

"Parate eksekusi merupakan pelaksanaan eksekusi hak kreditur atas obyek jaminan, tanpa (di luar) melalui ketentuan hukum acara, tanpa penyitaan, tanpa melibatkan juru sita, tanpa izin pengadilan". ${ }^{46}$

Dari segi sejarahnya, diterimanya lembaga parate eksekusi sebagai salah satu sarana pelunasan piutang kreditur, mengalami perdebatan yang sengit di Parlemen Belanda saat itu. Hal ini karena pembuat undang-undang saat itu dihadapkan pada dua realitas yang dilematis, yaitu disatu sisi lembaga pemberi kredit menunjukan trend menurun dalam memberikan bantuan kreditnya, hal ini disebabkan ketakutan kreditur untuk melakukan penagihan apabila debitur wanprestasi, karena kreditur yang telah memberikan kredit memiliki kepentingan untuk memutarkan harta dan assetnya agar memberikan keuntungan baginya, sedangkan apabila kredit yang telah ia berikan tersebut macet maka upaya untuk melakukan penagihan dan pelunasan melalui proses gugat-menggugat di Pengadilan akan memakan waktu yang lama, hal ini tidak sebanding dengan pengorbanan yang telah ia keluarkan (terancam kehilangan uangnya kemudian harus membuang banyak

\section{${ }^{45}$ Ibid.}

${ }^{46}$ Satrio, Hukum Jaminan, Op. Cit., hal. 307 
waktu mengambil kembali uangnya tersebut). Sedangkan disisi lain, pembuat undang-undang dihadapkan pada kenyataan bahwa rakyat kecil saat itu membutuhkan sekali kucuran kredit untuk menjalankan usahanya. Tapi pada kenyataannya rakyar kecil tersebut terpaksa harus meminjam kepada lintah darat, karena lembaga pemberi kredit (Bank) tidak mau memberikan kreditnya dengan alasan yang telah dijelaskan sebelumnya.

Sampai dengan saat-saat terakhir pengesahan Burgerlijke Wetboek, akhirnya pembuat undang-undang, lebih memilih menyelamatkan rakyat kecil, karena patut disadari bahwa kegiatan usaha menengah dan kecil sangat signifikan meningkatkan perekonomian negara. Yaitu dengan mengakomodir lembaga parate eksekusi sebagai (jalan keluar permasalahan ini) sarana bagi kreditur menjual obyek jaminan dalam Burgerlijke Wetboek. Mengenai hal ini J. Satrio menjelaskan sebagai beriku:

“... bahwa yang namanya menagih hutang melalui suatu gugatan di Pengadilan, dari mulai gugatan dimasukkan sampai pada pelaksanaan eksukusi, baik dizaman dahulu maupun sekarang, memakan waktu yang lama, dan sehubungan dengan itu memakan biaya yang relatif besar. Akibatnya, Bank-bank = sebagai lembaga pemberi kredit yang resmi, yang dalam praktek paling banyak menggunakan lembaga gadai- akan enggan untuk memberikan kredit kepada nasabah kecil-kecil, karena kalau terjadi, bahwa nantinya kredit itu macet, maka waktu yang tersita untuk mengurus penagihan akan lama sekali, dan biayanya bisa tidak imbang dengan tagihan yang hendak dikejar melalui gugatan itu (A.S. van Nierop, Hypotheek, 1937, hal. 155-156). Kalau demikian, maka nasabah-nasabah kecil terpaksa akan mencari pinjaman uangnya kepada para lintah darat, yang pada umumnya tidak menuntut banyak syarat, kecuali bunga yang tinggi. Pembuat undang-undang pada waktu itu dihadapkan pada pilihan, ia biarkan orang kecil, yang membutuhkan pinjaman dicekik oleh lintah darat, atau ia berikan kepada Bank suatu sarana yang mudah dalam mengambil pelunasan, yang dengan perkataan lain menyetujui pemberian hak parate eksekusi. Pembuat undang-undang ternyata, demi untuk melindungi rakyat kecil, memilih yang kedua". ${ }^{47}$

${ }^{47}$ Satrio, Eksekusi Obyek Jaminan Gadai, Op. Cit., hal. 6-7. 


\section{Syarat Penjualan Umum}

Didalam Pasal 1 Peraturan Lelang (Vendu Reglement), diatur bahwa yang dimaksud dengan penjualan umum (openbare verkopingen) adalah:

"Pelelangan atau penjualan barang-barang yang dilakukan kepada umum dengan penawaran harga yang meningkat atau menurun atau dengan pemasukan harga dalam sampul tertutup, atau kepada orang-orang yang diundang atau sebelumnya diberitahu mengenai pelelangan atau penjualan itu, atau diizinkan untuk ikut-serta, dan diberi kesempatan untuk menawar harga, menyetujui harga yang ditawarkan atau memasukkan harga dalam sampul tertutup".

Didalam Pasal 1a Peraturan Lelang, dikatakan bahwa penjualan umum harus dilakukan dihadapan juru lelang. Jadi maksud dari penjualan umum yang diatur dalam lembaga Parate Eksekusi jaminan khusus adalah penjualan lelang.

Meskipun hanya Pasal 1155 KUHPerdata (yang mengatur Parate Eksekusi Obyek Gadai), yang dengan tegas menyatakan bahwa tujuan dari penjualan umum adalah untuk kreditur mengambil pelunasan hak tagihnya. Tetapi haruslah dipahami, di dalam hipotik, Hak Tanggungan dan fidusia, tujuan dari penjualan obyek jaminan adalah sama, yaitu untuk mengambil pelunasan atas hutang debitur.

Adapun maksud agar obyek jaminan dijual umum adalah agar didapat harga tertinggi dari hasil penjualan atau setidak-tidaknya obyek jaminan tersebut dijual dengan harga obyek tersebut yang berlaku dipasaran. J. Satrio mengatakan bahwa syarat penjualan "di muka umum" adalah syarat yang patut sekali, dan merupakan salah satu wujud jaminan pertanggungjawaban kreditur bahwa dalam pelaksanaan haknya untuk menjual atas kekuasaan sendiri tersebut "tidak menelantarkan kepentingan yang lain", dalam hal ini yang dimaksud adalah, kepentingan pemilik maupun pihak ketiga sesama kreditur. ${ }^{48}$ Dengan kata lain, syarat penjualan umum tiada lain dmaksudkan untuk mendapatkan harga tertinggi/pasaran.

${ }^{48}$ Satrio, Parate Eksekusi, Op. Cit., hal. 26. 
Van Nierop dan Vollmar menceritakan pada akhirnya lembaga parate eksekusi dimasukan oleh pembuat undang-undang dalam KUHPerdata, ${ }^{49}$ dengan syarat penjualan umum, dengan pertimbangan:

"Kita tidak melihat keberatan, yang cukup kuat untuk tidak mengizinkan para pihak memperjanjikan hak itu (parate eksekusi), kalau ada wanprestasi, menjual benda jaminan tersebut dimuka umum, dan melunasi dirinya sendiri dari hasil penjualan itu, asal disertai dengan kewajiban untuk mempertanggungjawabkan hasil penjualannya dan menjamin tidak menelantarkan kepentingan yang lainnya. ${ }^{50}$

Tetapi yang menjadi pertanyaan, apabila terhadap obyek jaminan yang telah memiliki harga pasar, dapatkah menyingkirkan ketentuan penjualan lelang ini? Untuk memahami hal ini, layaknya kita melihat analogi ketentuan parate eksekusi dalam gadai. Karena apabila kita melihat maksud penjualan umum adalah untuk mendapatkan harga pasar. Maka sangat logis ketentuan Pasal 1155 Ayat (2) KUHPerdata ${ }^{51}$ yang mengatur bahwa terhadap barangbarang yang mempunyai nilai pasar dan efek-efek yang dapat diperdagangkan di bursa, dapat dijual ditempat itu juga,(secara tertutup atau private selling) asalkan dengan perantara 2 (dua) orang makelar yang ahli dibidang tersebut. Mengenai hal ini J. Satrio mengatakan:

"... maka ketentuan Pasal 1155 ayat 2 B.W., yang mengatur tentang barang-barang yang mempunyai nilai pasaran atau yang diperdagangkan di bursa adalah logis sekali, kalau barang-barang seperti itu -menyimpang dari Pasal 1155 ayat 1

${ }^{49}$ Ibid., hal. 18. sebagaimana dikutip dari Nierop, A.S. van, Hypotheekrecht, serie Publik en Privaatrecht, cet. Ke-2, (Tjeenk Willing, Zwolle, 1937), hal. 156. dan Vollmar, H.F.A., Nederlands Burgerlijk Recht, Handleiding voor studie en praktijk, Jilid kedua, Zaken en Erfrecht, cet. Kedua, (Tjeenk Willing, Zwole, 1951), hal. 423.

so Ibid., sebagaimana dikutip dari Nierop, A.S. van, Ibid., hal. 155 dan Paul Scholten, Op. Cit., hal. 484.

${ }^{51}$ Pasal 1155 Ayat (2) KUHPerdata, menyatakan:

"Bila gadai itu terdiri dari barang dagangan atau dari efek-efek yang dapat diperdagangkan dalam bursa, maka penjualannya dapat dilakukan di tempat itu juga, asalkan dengan perantaraan dua orang makelar yang ahli dalam bidang itu". 
B.W.- tidak perlu dijual didepan umum. Kalau benda gadai mempunyai nilai pasar, baik dipasaran maupun di bursa (yang bisa dibaca dari berita pasar atau daftar harga/prijscourant), buat apa lagi mencari nilai pasar melalui lelang. Penjualan benda-benda seperti itu bisa dilakukan di pasar atau bursa (tidak perlu melalui lelang), asal penjualan itu dilakukan dengan perantaraan dua orang makelar yang ahli dalam perdagangan barang-barang itu (Pasal 1155 ayat 2 B.W.). Ini sekali lagi menggambarkan, bahwa pembuat undang-undang memang hendak memberikan kemudahan-kemudahan bagi kreditur pemegang-gadai dalam mengambil pelunasan atas hak tagihnya". 52

Berdasarkan ketentuan eksekusi obyek gadai tersebut, dapatlah kita menganalogikan pengaturan ini dengan kewajiban penjualan umum dalam pengaturan parate eksekusi lembaga jaminan khusus lainnya, (meskipun dalam) hipotik, hak tanggungan dan fidusia hal ini tidak dengan tegas diatur.

Selain itu, kewajiban penjualan umum dapat disingkirkan dengan kesepakatan yang dibuat para pihak mengenai cara penjualan obyek jaminan: $\mathrm{Hal}$ ini dapat dilihat dari anak kalimat pertama Pasal 1155 Ayat (1) "Bila oleh pihak-pihak yang berjanji tidak disepakati lain" dan Pasal 29 Ayat (1) Huruf (c) Undang-Undang No. 42 Tahun 1999 Tentang Fidusia, yang menyatakan: "penjualan di bawah tangan yang dilakukan berdasarkan kesepakatan Pemberi dan Penerima Fidusia jika dengan cara demikian dapat diperoleh harga tertinggi yang menguntungkan para pihak".

Berdasarkan penjelasan diatas, dapatlah disimpulkan kewajiban penjualan umum tersebut tidaklah mutlak tapi dapat disingkirkan dengan syarat:

1. Adanya kesepakatan para pihak untuk menyingkirkan hal tersebut (kewajiban penjualan umum); atau jika tidak disepakati

2. Apabila obyek jaminan tersebut memiliki harga pasar, sehingga dapat dijual ditempat itu juga (pasar atau bursa). Sedangkan untuk menjamin agar kreditur "tidak menelantarkan kepentingan yang lain (debitur dan pihak ketiga)", maka sejalan dengan pengaturan gadai, penjualan ditempat tersebut harus dilakukan dengan perantara dua orang makelar yang ahli dibidang perdagangan tersebut.

${ }^{52}$ Satrio, Eksekusi Obyek Jaminan Gadai, Op. Cit., hal. 7. 
B.W.- tidak perlu dijual didepan umum. Kalau benda gadai mempunyai nilai pasar, baik dipasaran maupun di bursa (yang bisa dibaca dari berita pasar atau daftar harga/prijscourant), buat apa lagi mencari nilai pasar melalui lelang. Penjualan benda-benda seperti itu bisa dilakukan di pasar atau bursa (tidak perlu melalui lelang), asal penjualan itu dilakukan dengan perantaraan dua orang makelar yang ahli dalam perdagangan barang-barang itu (Pasal 1155 ayat 2 B.W.). Ini sekali lagi menggambarkan, bahwa pembuat undang-undang memang hendak memberikan kemudahan-kemudahan bagi kreditur pemegang-gadai dalam mengambil pelunasan atas hak tagihnya". 52

Berdasarkan ketentuan eksekusi obyek gadai tersebut, dapatlah kita menganalogikan pengaturan ini dengan kewajiban penjualan umum dalam pengaturan parate eksekusi lembaga jaminan khusus lainnya, (meskipun dalam) hipotik, hak tanggungan dan fidusia hal ini tidak dengan tegas diatur.

Selain itu, kewajiban penjualan umum dapat disingkirkan dengan kesepakatan yang dibuat para pihak mengenai cara penjualan obyek jaminan: $\mathrm{Hal}$ ini dapat dilihat dari anak kalimat pertama Pasal 1155 Ayat (1) "Bila oleh pihak-pihak yang berjanji tidak disepakati lain" dan Pasal 29 Ayat (1) Huruf (c) Undang-Undang No. 42 Tahun 1999 Tentang Fidusia, yang menyatakan: "penjualan di bawah tangan yang dilakukan berdasarkan kesepakatan Pemberi dan Penerima Fidusia jika dengan cara demikian dapat diperoleh harga tertinggi yang menguntungkan para pihak".

Berdasarkan penjelasan diatas, dapatlah disimpulkan kewajiban penjualan umum tersebut tidaklah mutlak tapi dapat disingkirkan dengan syarat:

1. Adanya kesepakatan para pihak untuk menyingkirkan hal tersebut (kewajiban penjualan umum); atau jika tidak disepakati

2. Apabila obyek jaminan tersebut memiliki harga pasar, sehingga dapat dijual ditempat itu juga (pasar atau bursa). Sedangkan untuk menjamin agar kreditur "tidak menelantarkan kepentingan yang lain (debitur dan pihak ketiga)", maka sejalan dengan pengaturan gadai, penjualan ditempat tersebut harus dilakukan dengan perantara dua orang makelar yang ahli dibidang perdagangan tersebut.

${ }^{52}$ Satrio, Eksekusi Obyek Jaminan Gadai, Op. Cit., hal. 7. 
Pengadilan Negeri Bandung, hal ini berdasarkan ketentuan Pasal 224 HIR. $^{54}$

Berdasarkan fakta tersebut diatas dapatlah dikatakan bahwa telah terjadi dua pertentangan yaitu ketentuan perundang-undangan yang mengatur parate eksekusi (hukum materil perdata) melawan kekuasaan kehakiman (hukum formil perdata). Pertentangan ini nyata dengan adanya pendapat dari DR. Rudhi Prasetya, S.H. dalam Seminar Grosse Akta yang diselenggarakan pada tanggal 23 Januari 1990 di Jakarta, yang memuji sikap Kepala Kantor Lelang yang menolak melaksanakan lelang tanpa adanya perintah Ketua Pengadilan Negeri. Menurut Rudhi Prasetya sikap tersebut didasarkan pada ketentuan Pasal 33 Ayat (3) Undang-undang No. 14 Tahun 1970 (atau Pasal 36 Ayat (3) Undang-undang No. 4 Tahun 2004) ${ }^{55}$ yang menutup kemungkinan kreditur menggunakan sarana parate eksekusi untuk mendapatkan pelunasannya.

Bila kita melihat pada permasalahan yang dipaparkan diatas, dimana lembaga peradilan menutup kemungkinan kreditur menggunakan lembaga parate eksekusi yang diatur dalam KUHPerdata (gadai dan hipotik) hal ini mungkin "dengan sangat terpaksa" dapat dimaklumi bahwa KUHPerdata merupakan konkordansi dalam sistem hukum Indonesia bukan merupakan produk legislasi yang dihasilkan oleh Lembaga Legislatif Indonesia (DPR RI). Tetapi yang menjadi permasalahan selanjutnya adalah, bagaimana dengan kenyataan bahwa lembaga parate eksekusi tersebut "dihidupkan kembali" didalam UU Hak Tanggungan dan UU Fidusia, dimana kedua undang-undang yang didalamnya mengatur parate eksekusi tersebut merupakan produk legislasi DPR RI yang memiliki daya keberlakuan secara filosofis, politis, yuridis, sosiologis dan secara administratif, ${ }^{56}$ serta merupakan kehendak rakyat (bila mengacu pada ilmu perundang-undangan dan demokrasi). Maka sangat tidak relevan apabila dewasa ini lembaga parate eksekusi tetap tidak dapat digunakan.

Mengenai penolakan lembaga peradilan terhadap lembaga parate eksekusi ini, dapatlah disimpulkan bahwa lembaga peradilan terlalu "arogan" menggunakan kekuasaannya dengan menutup kemungkinan penggunaan

${ }^{54}$ Mura P. Hutagalung. "Eksekusi Hipotik dan Kepastian Hukumnya”. Jurnal Hukum dan Pembangunan No. 6 Tahun ke-20, Desember 1990. hal. 562

55 Pasal 33 Ayat (3) Undang-undang No. 14 Tahun 1970 atau Pasal 36 Ayat (3) Undang-undang No. 4 Tahun 2004. berbunyi: "Pelaksanaan putusan pengadilan dalam perkara perdata dilakukan oleh panitera dan juru sita dipimpin oleh ketua pengadilan. hal. 240 .

56 Jimly Asshiddiqie, "Perihal Undang-undang". (Jakarta: Konstitusi Press. 2006). 
lembaga parate eksekusi. Sikap lembaga peradilan tersebut tidaklah berdasar, dengan alasan:

1. Sebagaimana telah dijelaskan pada pembahasan sebelumnya bahwa pengaturan parate eksekusi adalah suatu pengaturan lembaga eksekusi yang ditujukan untuk menderogasi ketentuan hukum formil, yang oleh A. Pitlo dan P.A. Stein dikatakan sebagai "buiten het terrein der rechtvordering" (di luar wilayah hukum acara).

2. Eksistensi parate eksekusi diatur dalam Undang-undang, sehingga perlawanan terhadap ketentuan perundang-undangan merupakan perbuatan melawan hukum. Hal ini sangat bertolak belakang dengan tugas Mahkamah Agung untuk membina keseragaman dalam penerapan hukum dan mengajar agar semua hukum dan undang-undang diseluruh wilayah Negara diterapkan secara tepat dan adil. ${ }^{57}$

3. Tidak tepat mendasarkan ketidakberlakukan lembaga parate eksekusi pada Yurisprudensi Mahkamah Agung, karena berdasarkan poin no. 2 Mahkamah Agung melalui putusan dan penetapannya memberikan keseragaman pemahaman hukum bukan menderogasi suatu lembaga hukum yang dengan tegas diatur dalam undang-undang. Selain itu yurisprudensi tidak dapat menderogasi ketentuan di dalam undang-undang karena yurisprudensi hanya merupakan salah satu sumber hukum yang menjadi dasar dalm pembentukan hukum, lagipula yurisprudensi tidak terdapat dalam tata urutan perundang-undangan yang dapat menyatakan suatu ketentuan undang-undangan tidak berlaku atau bertentangan.

Oleh karena itu, dengan tegas harus dikatakan bahwa lembaga parate eksekusi "seharusnya" masih tetap eksis dan "dapat digunakan" oleh kreditur pemegang obyek jaminan khusus kebendaan untuk mendapatkan pelunasan piutangnya dengan mudah dan sederhana. Adapun ketidakeksisan lembaga parate eksekusi justru disebabkan oleh rasa "arogan" dan "sensitivitas" lembaga peradilan karena dilompatinya peranan dan kewenangannya dalam lingkup eksekusi. Padahal bila kita melihat filosofis dari diciptakannya lembaga parate eksekusi di Belanda dulu, memang ditujukan untuk melompati (berada diluar) kewenangan lembaga peradilan (yang identik dengan prosedur yang rumit dan memakan waktu yang lama)

57 Mahkamah Agung RI, "Buku III Pedoman Organisasi dan Administrasi Mahkamah Agung Rl", (Jakarta, 2006), hal. 6. 
demi tercapainya konsep memudahkan dan sederhana bagi kreditur mendapatkan pelunasannya (yang mana hal ini merupakan sifat dari lembaga jaminan kebendaan khusus) demi lancarnya pemberian kredit kepada rakyat kecil.

Mungkin untuk mengekspresikan kenyataan dan permasalahan ini dapat diungkapkan dengan pertanyaan, "Jikalau eksekusi obyek jaminan kebendaan khusus (parate eksekusi) harus melalui mekanisme hukum formal (apalagi gugat-menggugat) di pengadilan, maka apa yang membedakan jaminan kebendaan khusus dengan jaminan kebendaan umum (yang diatur dalam Pasal 1131 dan 1132 KUHPerdata)?"

\section{Penutup}

Pada praktek penjualan obyek jaminan khusus yang bersifat kebendaan, dewasa ini sering sekali mengalami banyak hambatan. Terkadang permasalahan tersebut, menjadikan pemberi kredit (Bank) menjadi enggan mengucurkan kreditnya dengan segala kemudahan. Meskipun nyatanya dalam memberikan kredit telah dipersyaratkan apa yang dikenal dengan aspek 5C (Character, Capacity, Capital, Collateral, Condition of Economy), tetap saja kreditur akan mengalami berbagai kendala untuk mengambil pelunasan piutangnya (eksekusi), karena apabila kita melihat pada asas kesebandingan maka dengan apa yang telah dikorbankan oleh kreditur dengan apa yang ia perolehnya tidaklah seimbang.

Mengenai permasalahan ini, undang-undang telah memberikan jalan keluarnya dalam lembaga parate eksekusi, dimana kreditur diberikan hak berupa kemudahan dan prosedur sederhana untuk mendapatkan pelunasan hak tagihnya, karena dapat dilakukan tanpa melibatkan kreditur dan tanpa perantara pengadilan. Hal ini sangatlah logis, karena (bila dikaitkan dengan sifat hak jaminan yang bersifat perbendaan) kreditur melaksanakan apa yang merupakan haknya (pelunasan piutang). Sehingga apabila syarat-syarat untuk melakukan parate eksekusi telah terpenuhi, maka kreditur tinggal datang ke Kantor Lelang Negara (dengan membuktikan adanya hak atas piutang, kewenangan untuk menjual sendiri, wanprestasinya debitur) untuk kemudian melelang benda tersebut dan mengambil pelunasan atas hasil penjualan tersebut.

Tapi menjadi sangat miris sekali ketika pada praktek, Kantor Lelang Negara pada umumnya tidak berani melakukan lelang tanpa adanya fiat eksekusi dari Ketua Pengadilan Negeri. ${ }^{58}$ Sehingga dapat dikatakan jika 
kreditur ingin melakukan parate eksekusi, maka ia harus diposisikan sebagai orang yang memenangi perkara, karena pelaksanaan hak tersebut hanya dapat terjadi dengan adanya fiat eksekusi tersebut. ${ }^{59}$ Padahal undang-undang dan doktrin telah mengatur betapa sederhananya pelaksanaan parate eksekusi tersebut, karena kreditur melaksanakan hak tersebut layaknya ia menjual bendanya sendiri. Parate eksekusi merupakan prosedur eksekusi yang berada pada rezim hukum perdata materiil karena hal ini merupakan hak essensial dari kreditur (keutamaan dari lembaga jaminan kebendaan), bukan merupakan pengaturan mengenai prosedural untuk menegakkan hak tersebut, yang masuk dalam rezim hukum perdata formil (hal ini terlihat dari tidak dilibatkannya aparatur peradilan dalam eksekusi tersebut). Kerancuan timbul, karena apabila dicermati, ternyata ketentuan lelang, dominan berada dalam rezim hukum perdata formil, padahal bila mengacu pada pengaturan lembaga parate eksekusi ini kenyataannya tidaklah demikian. Dengan kenyataan ini sangat jelas bahwa pada praktek dewasa ini, telah terjadi salah pemahaman mengenai maksud (filosofis), teori dan peraturan hukum mengenai lembaga parate eksekusi tersebut.

Melihat praktek pelaksanaan parate eksekusi yang harus dengan fiat eksekusi, mengingatkan bahwa Hukum Jaminan Kebendaan Indonesia saat ini sama dengan Hukum Jaminan Jerman Kuno (germaansrecht) dimana semua penjualan harus melalui Hakim, dan Hukum Jaminan Belanda Kuno, dimana penjualan obyek jaminan harus berdasarkan Keputusan dan di bawah Pengawasan Pengadilan, yang saat ini sudah jauh-jauh ditinggalkan oleh kedua negara tersebut. ${ }^{60}$ Karena hal tersebut tidak relevan lagi, dengan perkembangan perekonomian dewasa ini.

\footnotetext{
${ }^{58}$ lbid.

${ }^{59}$ Satrio, Hukum Jaminan Hak Jaminan Kebendaan, Op. Cit., hal. 307.

${ }^{60}$ Satrio, Parate Eksekusi, Op. Cit., hal. 16.
} 


\section{Daftar Pustaka}

\section{Buku}

Gautama, Sudargo. Komentar Atas Undang-Undang Hak Tanggungan Baru Tahun 1996 No. 4. Cet. ke-1. Bandung: Citra Aditya Bakti. 1996.

Mahkamah Agung RI. Buku III Pedoman Organisasi dan Administrasi Mahkamah Agung RI. Jakarta, 2006.

Mertokusumo, Sudikno. Hukum Acara Perdata Indonesia. Yogyakarta: Liberty. 1996.

Prodjodikoro, Wirjono. Hukum Perdata Tentang Hak Atas Benda. Cet. ke-5. Jakarta: Intermasa. 1986.

Satrio, J. Parate Eksekusi Sebagai Sarana Menghadapi Kredit Macet. Bandung: Citra Aditya Bakti. 1993.

Satrio, J. Hukum Jaminan Hak Jaminan Kebendaan. Bandung: Citra Aditya Bakti. 2002.

Setiawan. Aneka Masalah Hukum Dan Hukum Acara Perdata. Bandung: Alumni. 1992.

Sofwan, Sri Soedewi Masjchoen. Hukum Perdata: Hukum Benda. Cet. ke-4, Yogyakarta: Liberty. 1981.

\section{Artikel dan Prosiding}

Asshiddiqie, Jimly. "Perihal Undang-undang". Konstitusi Press. Jakarta. 2006.

Darmabrata, Wahyono. dan Ari Wahyudi Hertanto. "Jual Beli dan Aspek Peralihan Hak Milik Suatu Benda (Dalam Konstruksi Gadai Saham)". Jurnal Hukum dan Pembangunan No. 1 Tahun ke-35. Januari-Maret 2005.

Elijana, Maria Elisabeth. Eksekusi Barang Jaminan Sebagai Salah Satu Cara Pengembalian Hutang Debitur, Prosiding Seminar Sehari Perbankan, Aspek Hukum Corporate Financing Oleh Perbankan di Indonesia: Aturan Penegakan dan Penyelesaian Sengketa Hukum Dalam Hubungan Kreditor dan Debitor, Jurnal Hukum dan Pembangunan FHUI. Jakarta. 2006. 
Hutagalung, Mura P. ."Eksekusi Hipotik dan Kepastian Hukumnya". Jurnal Hukum dan Pembangunan No. 6 Tahun ke-20. Desember 1990.

Satrio, J. Eksekusi Benda Jaminan Gadai. Prosiding Seminar Sehari Perbankan. Aspek Hukum Corporate Financing Oleh Perbankan di Indonesia: Aturan Penegakan dan Penyelesaian Sengketa Hukum Dalam Hubungan Kreditor dan Debitor. Jurnal Hukum dan Pembangunan FHUI. Jakarta. 2006

\section{Peraturan Perundang-undangan}

Kitab Undang-Undang Hukum Perdata.

Kitab Undang-Undang Hukum Dagang.

Peraturan Lelang (Vendu Reglement), Peraturan Penjualan Umum Di Indonesia, Ordonansi 28 Februari 1908. Stbl. 1908-189.

Indonesia, Undang-Undang No. 4 Tahun ${ }^{`} 1996$ Tentang Hak Tanggungan Atas Tanah Beserta Benda-Benda Yang Berkaitan Dengan Tanah. , Undang-Undang No. 42 Tahun 1999 Tentang Fidusia. 